\title{
RANCANG BANGUN APLIKASI PEMBELAJARAN TARIAN TRADISIONAL MENGGUNAKAN KINECT
}

\author{
Ari Zanupratama ${ }^{1}$, Mungki Astiningrum²
}

${ }^{1}$ Teknik Informatika, Teknologi Informasi, Politeknik Negeri Malang

${ }^{1}$ arizanupratama@gmail.com, ${ }^{2}$ mungki_astiningrum@polinema.ac.id

\begin{abstract}
Abstrak
Kurangnya akan informasi dan pengetahuan akan budaya Indonesia mengakibatkan kurangnya apresiasi terhadap budaya Indonesia khusunya pada tari tradisional. Padahal dengan kemajuan teknologi pada saat ini pembelajaran terhadap budaya Indonesia dapat diterapkan melalui cara yang lebih interaktif. Salah satunya adalah memanfaatkan teknologi depth sensor yang ada di dalam Microsoft Kinect. Dengan adanya teknologi ini, memungkinkan seseorang untuk dapat berinteraksi dengan perangkat komputer melalui gerakan, wajah, dan suara. Kemampuan interaksi tersebut khususnya dalam mendeteksi gerakan dapat dijadikan sebagai alat pembelajaran budaya Indonesia khususnya budaya tarian tradisional. Oleh karena itu dibuat aplikasi pembelajaran tarian tradisional dengan harapan dapat membuat aplikasi pembelajaran tarian tradisional yang interaktif serta dapat meningkatkan apresiasi seseorang akan budaya Indonesia khususnya tarian tradisional.
\end{abstract}

Kata Kunci: Kinect, Depth Sensor, Aplikasi Pembelajaran, Tari Tradisional

\section{Pendahuluan}

Dengan masuknya budaya-budaya asing secara bebas di Indonesia, membuat masyarakat khususnya generasi muda kurang melestarikan budaya tradisional Indonesia. Mereka cenderung tertarik ke budaya negara asing daripada budaya negara mereka sendiri. Bahkan tidak sedikit dari masyarakat tidak mengetahui budaya daerah asal mereka sendiri. Hal ini disebabkan kurangnya informasi dan pengetahuan terhadap budaya-budaya tradisional Indonesia.

Berbeda dengan budaya-budaya asing yang informasinya banyak muncul di berbagai macam media seperti film, lagu, bahkan permainanpermainan yang disajikan dengan interaktif dan menarik. Apalagi dengan kemajuan teknologi pada saat ini yang membuat informasi tersebut dapat masuk bebas di wilayah Indonesia.

Kemampuan berinteraksi terhadap perangkat komputer pada saat ini pun sudah bermacam-macam. Seperti mouse, keyboard, joystick, dan touchscreen. Bahkan kemampuan berinteraksi saat ini pun dapat menggunakan gerakan anggota tubuh. Salah satunya adalah teknologi buatan Microsoft yang bernama Kinect. Kinect merupakan perangkat yang mampu mendeteksi gerakan, wajah dan suara yang nantinya dapat digunakan sebagai input dalam berbagai macam permainan ataupun interaksi-interaksi lainnya. Input tersebut dideteksi oleh depth sensor yang ada di dalam Kinect. Depth sensor sendiri merupakan fitur dari Kinect yang terdiri atas kombinasi dari infrared laser projection dan monochrome CMOS sensor yang berperan untuk mendapatkan data video dalam kondisi tiga dimensi.

Oleh karena itu penulis akan membuat aplikasi pembelajaran tarian dengan menggunakan teknologi Kinect dengan harapan dapat meningkatkan apresiasi masyarakat terhadap budaya tradisional Indonesia.

\section{Landasan Teori}

\subsection{Kinect}

Di dalam Kinect terdapat sensor yang bernama depth sensor. Depth Sensor merupakan fitur utama dari Kinect dalam mendeteksi gerakan. Depth Sensor terdiri atas kombinasi dari infrared laser projection dan monochrome CMOS sensor.



Gambar 1. Depth Sensor Kinect

Infrared Laser berperan sebagai pemancar cahaya invisible near-infrared ke seluruh bagian ruangan yang terjangkau oleh Kinect. Cahaya ini merupakan cahaya kelas I yang tidak berbahaya bagi manusia. Sedangkan monochrome CMOS sensor merupakan sensor yang berperan dalam menghitung jarak suatu objek dengan mengukur waktu penerbangan cahaya setelah terpantul ke suatu objek 
tersebut. Dengan menggunakan dua kombinasi sensor tersebut, Kinect akan mendapatkan data video dalam kondisi tiga dimensi.

\subsection{Multimedia Interaktif}

Multimedia interaktif merupakan perpaduan berbagai media yang berbeda yang dikemas menjadi sebuah file digital. (Ratini, 2011). Dengan kata lain Multimedia Interaktif memanfaatkan media komputer dan software pengolah gambar, animasi, dan suara. Dengan multimedia interaktif, dapat menyajikan informasi dengan objek abstrak menjadi konkrit serta dapat memberikan pengalaman langsung terhadap seseorang yang menggunakannya..

\subsection{Tari Topeng Malangan}

Wayang topeng awalnya merupakan sarana untuk upacara yang bersifat sakral dengan penari yang memakai topeng dan disertai dialog yang dilakukan oleh seorang dalang. Namun kemudian berkembang menjadi hiburan biasa. Cerita yang diambil antara lain Mahabarata, Ramayana, atau cerita Panji. Tari topeng merupakan tari yang dibawa oleh Surya Atmojo yang dulunya menjadi abdi dalam keraton majapahit yang mengungsi ke daerah Malang sambil membawa topeng dan ketrampilan menarinya. Bupati di kabupaten Malang tertarik dengan keahlian Surya Atmojo sebagai penari topeng dan akhirnya menetapkan tari topeng sebagai tarian khas Malang.

\section{Metodologi Penelitian}

Metode penelitian dibagi atas lima tahap. Yakni Analisis, desain, implementasi, pengujian, dan dokumentasi.

\subsection{Analisis}

Pada tahap ini, dilakukan analisis terhadap aplikasi yang akan dibuat. Seperti cara kerja sistem, menentukan teknik yang digunakan, serta mencari semua kebutuhan yang diperlukan untuk membuat aplikasi ini.

Untuk pembuatan aplikasi ini akan menggunakan Unity sebagai tools utama untuk membangun sistem. Dan untuk dapat menggunakan perangkat Kinect sebagai input gerakan pada Unity, dibutuhkan aset tambahan yaitu Kinect with MSSDK. Selain itu dibutuhkan juga aset yang bernama Playmaker untuk membuat alur sebuah objek dan memanggil fungsi-fungsi yang telah ada.

Teknik yang dibutuhkan pada aplikasi pembelajaran ini adalah teknik gesture recognition yang merupakan teknik untuk mendeteksi gerakan yang dilakukan oleh objek yang kemudian dapat digunakan sebagai input gerakan.
Untuk materi pembelajaran akan menggunakan video hasil rekaman dari penari Topeng Malangan dari Sanggar Topeng Malangan Handoyo yang terletak di Jln. Prajurit Slamet Dk. Kedung Monggo Karangpandan, Pakisaji Malang, Jawa Timur.

\subsection{Desain}

. Pada tahap ini dilakukan perancangan terhadap apa yang dibutuhkan di dalam aplikasi. Selain itu pada tahap ini dilakukan perancangan cara kerja sistem aplikasi yang dibuat. Pada aplikasi pembelajaran ini terdapat 3 mode pembelajaran yaitu mode training, showcase, dan watch video.

\subsection{Implementasi}

Pada tahap ini dilakukan pengerjaan terhadap aplikasi dengan menggabungkan hasil analisis dengan desain yang telah dibuat. Spesifikasi yang digunakan pada tahap ini adalah:

Spesifikasi software:

- Sistem operasi Windows 8.1

- Microsoft Kinect Software Development Kit

- Unity 5

- Aset Kinect with MS-SDK

- Aset Playmaker

Sony Vegas 10

Spesifikasi Hardware:

- Processor Intel i7 Haswell

- RAM 8GB

- Nvidia GT 755M 2GB

- Microsoft Kinect XBOX360 dengan Adapter

\subsection{Pengujian}

Pengujian dilakukan dengan menggunakan alpha testing dan beta testing dimana pengujian alpha testing dilakukan oleh pembuat software sendiri dan beta testing, dimana pengujian dilakukan oleh user melalui kuesioner.

\subsection{Dokumentasi}

Pada tahap ini dilakukan pembuatan dokumentasi yang diperlukan serta pembuatan laporan hasil.

\section{Analisis dan Perancangan}

\subsection{Analisis}

Aplikasi pembelajaran tarian tradisional ini menggunakan Kinect with MS-SDK yang merupakan salah satu aset dari Unity. Aset ini berfungsi sebagai perantara antara Unity dengan Kinect melalui Kinect SDK dan menyediakan beberapa gesture yang dapat digunakan sebagai kontrol di dalam aplikasi. Selain 
itu aplikasi ini juga menggunakan Playmaker untuk membuat alur jalannya aplikasi.

Pada awalnya, dengan menggunakan depth sensor dari Kinect, akan diketahui suatu pemetaan objek manusia beserta dengan jaraknya. Hasil pemetaan tersebut kemudian akan diproses melalui Kinect SDK yaitu dengan membandingkan hasil pemetaan objek dengan 100.000 frame data training objek manusia yang ada di dalam Kinect SDK. Setelah diproses, titik-titik sendi yang ada pada objek akan terdeteksi. Titik Hasil dari titik-titik sendi ini dapat dipanggil oleh Unity melalui aset Kinect with MS-SDK yang kemudian dapat digunakan untuk membuat gesture serta interaksi dengan berbagai objek yang ada di dalam Unity.

Hasil titik-titik sendi objek manusia yang terdeteksi dapat digunakan untuk membuat gesture recognition dengan menentukan hubungan antara titik sendi. Seperti hubungan antara titik sendi bahu kanan dan titik sendi tangan kanan. Dengan berpusat pada titik sendi bahu kanan, apabila jarak ketinggian titik sendi tangan kanan lebih tinggi daripada titik sendi bahu kanan, maka objek sedang mengangkat tangan. Begitu juga sebaliknya apabila titik sendi tangan kanan lebih rendah daripada titik sendi bahu kanan maka objek sedang menurunkan tangannya.

\subsection{Perancangan}

Dalam perancangan materi tarian yang akan digunakan sebagai pembelajaran di dalam aplikasi ini adalah Tari Bapang yang dimana gerakannya merupakan gerakan yang paling simpel dari sekian jenis Tari Topeng Malangan.

Di dalam aplikasi ini terdapat tiga mode yaitu mode traning, mode showcase, dan mode watch video.

Mode training merupakan mode latihan dimana pembelajaran dilakukan secara bertahap atau step-bystep. Dalam mode pembelajaran ini, video akan pause ketika mencapai suatu gerakan. Dan ketika user telah mengikuti gerakan tersebut, video akan lanjut dan pause ke gerakan berikutnya. Proses ini akan berlanjut sampai video berakhir. Setiap pose gerakan pada mode ini dikenali dengan menggunakan gesture recognition.

Mode showcase merupakan mode pembelajaran yang dilakukan secara penuh dengan mengikuti video dari awal sampai akhir. Pada mode ini, user yang terdeteksi akan menggerakkan sebuah hidden cubeman yang akan bergerak sesuai dengan pergerakan user. Di dalam mode ini juga terdapat dua marker yang berfungsi untuk menentukan ketepatan pergerakan dari user. Yaitu marker yang terletak di titik sendi tangan kanan dan kiri pada hidden cubeman, dan marker perfect yang diletakkan sesuai dengan posisi gerakan pada video. Apabila marker pada tangan hidden cubeman mengenai marker perfect maka user akan dianggap perfect dan apabila marker pada tangan hidden cubeman tidak berada di marker perfect pada waktunya, maka user akan dianggap miss. Di akhir mode, terdapat tampilan result yang akan menampilkan jumlah miss dan perfect yang telah dilakukan oleh user, serta completion yang merupakan persentase keberhasilan yang telah dilakukan oleh $u$ ser.

Pada mode watch video user dapat menonton video materi gerakan tarian secara penuh.

Di dalam aset Kinect with MS-SDK telah tersedia 20 gesture yang dapat digunakan. Pada aplikasi ini hanya beberapa gesture dari aset tersebut yang digunakan sebagai keperluan navigasi yaitu:

- RightHandCursor sebagai kursor

- RaiseRightHand sebagai start pada mode training dan showcase serta navigasi screenshot pada mode showcase

- RaiseLeftHand sebagai navigasi screenshot pada mode showcase

- Wave sebagai pause pada mode training

- Psi sebagai kembali ke menu utama pada mode showcase.

Pada mode training memerlukan gesture khusus yang tidak terdapat di dalam aset tersebut. Oleh karena itu diperlukan adanya gesture baru yang sesuai dengan gerakan pada video. Di dalam aset Kinect with MS-SDK terdapat sebuah file sebagai pengontrol dan menyimpan gesture yaitu Kinectgestures.cs. Nilai yang berasal dari depth sensor yang berupa titik sendi utama dapat dipanggil sebagai parameter untuk membuat gesture. Titik-titik sendi utama yang dapat digunakan adalah sebagai berikut.

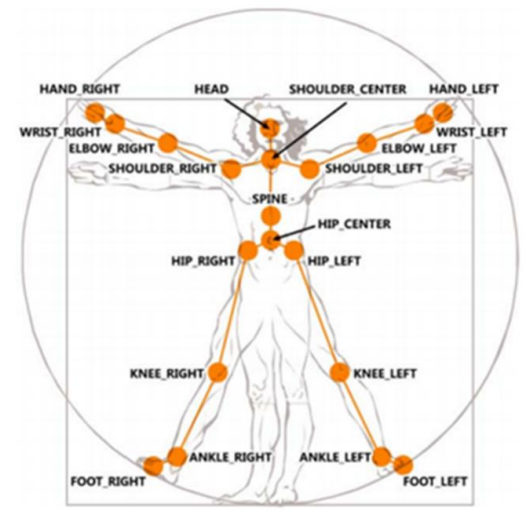

Gambar 2. Titik Sendi yang Dideteksi Kinect

Di dalam Kinectgestures.cs, titik sendi yang telah dipanggil hanya meliputi bagian tangan dan badan bagian tengah. Dan aplikasi ini memerlukan bagian kaki sebagai salah satu input. Oleh karena itu dibutuhkan titik sendi bagian kaki yaitu titik sendi lutut. Untuk memanggil nilai titik sendi lutut dapat dengan membuat variabel baru yang meyimpan titik sendi lutut dari Kinect SDK dengan menuliskan kode sebagai berikut. 
private const int rightKneeIndex = (int) KinectWrapper.NuiSkeletonPositionIndex.KneeR ight;

private const int leftKneeIndex $=$ (int) KinectWrapper. NuiSkeletonPositionIndex. KneeL eft;

Dari kode di atas diketahui bahwa posisi titik sendi dari lutut kanan dan kiri yang didapatkan dari Kinect disimpan di dalam variabel rightKneeIndex dan leftKneeIndex.

\section{Implementasi}

\subsection{Video Editing}

Untuk menghasilkan video materi tarian yang lebih baik, hasil rekaman tarian diedit dengan menggunakan Sony Vegas.

\subsection{Main Menu}

Pada main menu terdapat empat sub menu yaitu training, showcase, watch video, dan exit. Tampilan main menu adalah sebagai berikut.

\subsection{Mode Training}

Pada mode training dibutuhkan untuk membuat gesture tambahan yang sesuai dengan materi gerakan. Hal ini dilakukan dengan melakukan kode tambahan ke Kinectgestures.cs yang ada di dalam aset Kinect with MS-SDK. Setelah penambahan berhasil, nama gesture yang dibuat akan muncul di dalam Kinect manager dan dapat dipilih sebagai salah satu elemen gesture.

\subsection{Mode Showcase}

Pada mode showcase dibuat dengan menggunakan hidden cubeman yang kemudian di masing-masing tangan hidden cubeman diberikan rigidbody dan trigger. Setelah itu marker di tangan hiiden cubeman akan bereaksi apabila mengenai marker perfect atau perfect miss yang telah disediakan.

\section{Uji Coba dan Pembahasan}

\subsection{Uji Fungsional}

Tabel 1. Pengujian Deteksi Berdasarkan Jarak

\begin{tabular}{|c|c|}
\hline Jarak & Hasil \\
\hline 0.5 meter & $\begin{array}{c}\text { User tidak } \\
\text { terdeteksi }\end{array}$ \\
\hline $1-2$ meter & $\begin{array}{c}\text { User terdeteksi } \\
\text { namun badan tidak } \\
\text { tampak sepenuhnya }\end{array}$ \\
\hline $2-3$ meter & $\begin{array}{c}\text { User terdeteksi } \\
\text { penuh }\end{array}$ \\
\hline
\end{tabular}

Dari tabel di atas dapat diketahui bahwa pendeteksian user stabil pada jarak 2-3 meter.

Tabel 2. Pengujian Deteksi berdasarkan Cahaya

\begin{tabular}{|c|c|}
\hline Cahaya & Hasil \\
\hline Terang & User terdeteksi \\
\hline Redup & User terdeteksi \\
\hline Gelap & User terdeteksi \\
\hline
\end{tabular}

Dari tabel di atas dapat diketahui bahwa cahaya tidak mempengaruhi pendeteksian user.

Pada setiap bagian yang memerlukan custom gesture, masing-masing dilakukan uji coba dengan membandingkan tiga kondisi jarak setiap bagian gerakan yang berbeda. Hasil yang didapatkan adalah sebagai berikut.

Tabel 6.4 Pengujian Jarak Kondisi $<0.1 \mathrm{f}$

\begin{tabular}{|c|c|}
\hline Jarak & Hasil \\
\hline$<0.0 \mathrm{f}$ & Berfungsi \\
\hline 0.0f $-0.1 \mathrm{f}$ & Berfungsi \\
\hline$>0.1 \mathrm{f}$ & Tidak Berfungsi \\
\hline
\end{tabular}

Dari tabel diatas diketahui bahwa setiap gerakan yang mempunyai kondisi perbandingan jarak kurang dari $0.1 \mathrm{f}$ dapat berfungsi dengan baik.

Tabel 6.5 Pengujian Jarak Kondisi $>0.1 \mathrm{f}$

\begin{tabular}{|c|c|}
\hline Jarak & Hasil \\
\hline$<0.0 \mathrm{f}$ & Tidak Berfungsi \\
\hline 0.0f $-0.1 \mathrm{f}$ & Tidak Berfungsi \\
\hline$>0.1 \mathrm{f}$ & Berfungsi \\
\hline
\end{tabular}

Dari tabel diatas diketahui bahwa setiap gerakan yang mempunyai kondisi perbandingan jarak lebih dari $0.1 \mathrm{f}$ dapat berfungsi dengan baik.

Tabel 6.6 Pengujian Jarak Kondisi Mathf.Abs( $)<$

\begin{tabular}{|c|c|}
\multicolumn{1}{c}{$0.1 \mathrm{f}$} \\
\hline Jarak & Hasil \\
\hline$<0.0 \mathrm{f}$ & Tidak Berfungsi \\
\hline $0.0 \mathrm{f}-0.1 \mathrm{f}$ & Berfungsi \\
\hline$>0.1 \mathrm{f}$ & Tidak Berfungsi \\
\hline
\end{tabular}

Dari tabel diatas diketahui bahwa setiap gerakan yang mempunyai kondisi perbandingan jarak kurang dari absolute $0.1 \mathrm{f}$ dapat berfungsi dengan baik.

\subsection{Pengujian Performa}

Dalam pengujian performa aplikasi pembelajaran ini, user yang diambil berjumlah 10 orang yang terdiri dari 6 orang laki-laki dan 4 orang perempuan dimana 5 diantaranya pernah menggunakan dan memiliki pengetahuan yang cukup terhadap Kinect.

Hasil penilaian adalah sebagai berikut. 




Gambar 3. Grafik Rata-Rata

Dari grafik di atas dapat dilihat bahwa pengetahuan Kinect dari user yang diambil adalah kurang, penyampaian materi dinilai cukup, desain visual dinilai kurang mendekati cukup, keinteraktifan dinilai cukup mendekati baik, dan peningkatan apresiasi dinilai baik.

Untuk mengukur tingkat kepuasan pengguna aplikasi pembelajaran ini, dapat dilakukan dengan memperhatikan nilai dari pertanyaan ke 4 yaitu mengenai keinteraktifan dan pertanyaan ke 5 mengenai peningkatan apresiasi. Hasil yang didapatkan adalah sebagai berikut.

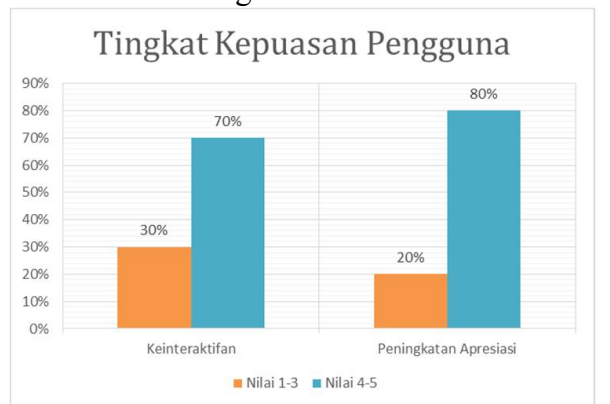

Gambar 4 Grafik Tingkat kepuasan Pengguna

Dari grafik diatas, dapat disimpulkan bahwa tingkat kepuasan pengguna pada sisi keinteraktifan adalah $70 \%$. Sedangkan tingkat kepuasan pengguna pada sisi peningkatan apresiasi adalah $80 \%$.

\section{Kesimpulan dan Saran}

\subsection{Kesimpulan}

Dari hasil pengujian yang telah dilakukan, dapat ditarik kesimpulan sebagai berikut.

- Dengan memanfaatkan depth sensor pada perangkat Kinect, mampu membangun sebuah aplikasi pembelajaran yang interaktif dibuktikan dengan tingkat kepuasan pengguna pada sisi keinteraktifan yaitu sebesar $70 \%$

- Melalui aplikasi pembelajaran ini, peniingkatan apresiasi seseorang terhadap budaya Indonesia khususnya tarian Topeng Malang bertambah, dibuktikan dengan tingkat kepuasan pengguna pada sisi peningkatan apresiasi sebesar $80 \%$..

\subsection{Saran}

Aplikasi pembelajaran ini dapat dikembangkan dari berbagai sisi. Mulai dari pengembangan desain visual materi yang dapat ditambahkan dengan beberapa tarian tambahan, penambahan kondisi pada mode showcase, penambahan difficulty atau tingkat kesulitan, dan penambahan pemain hingga menjadi 2 player.

\section{Daftar Pustaka:}

Amrulloh, Rizqi, dkk. 2013. Kelayakan Teoritis Media Pembelajaran Multimedia Interaktif Materi Mutasi Untuk SMA Vol.2 No.2. Surabaya: UNESA

Kamal, Mushtofa. 2010. Wayang topeng Malangan: Sebuah Kajian Historis Sosiologis . Malang: Universitas Negeri Malang

Mathe, Z. (2011). Inside Kinect: Skeletal Tracking Deep Dive. Dikutip pada tanggal Januari 28, 2015, dari Microsoft: http://www.microsoft.com/download/en/confir mation.aspx? $\mathrm{id}=26098$

Shotton, Jamie dkk. 2011. Real-Time Human Pose Recognition in Parts from Single Depth Images. Microsoft Research Cambridge \& Xbox Incubation

Sunaryono, Dwi, dkk. 2012. Integrasi Kinect dan Unreal Development Kit Menggunakan Kerangka Kerja OpenNI Pada Studi Kasus Game Berbasis Interaksi Gerakan Vol 01, No 1. Surabaya: Institut Teknologi Sepuluh November.

Yudithya, Willy. 2012. Perancangan Program Aplikasi Pembelajaran Bahasa Isyarat Dengan Metode Dynamic Time Warping . Jakarta Barat: Binus 